PRZEGLĄD RUSYCYSTYCZNY 2021, nr 3 (175)

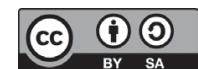

DOI 10.31261/pr.7636

IRYNA AHAPAVA

Katolicki Uniwersytet Lubelski Jana Pawła II

(iD) ORCID http://orcid.org/0000-0003-4403-3739

\title{
ЛЕКСИКО-ФРАЗЕОЛОГИЧЕСКИЕ СРЕДСТВА СОЗДАНИЯ ЭКСПРЕССИИ В МЕДИАТЕКСТЕ НА СПОРТИВНУЮ ТЕМУ
}

\author{
LEXICAL AND PHRASEOLOGICAL MEANS OF CREATING EXPRESSION IN THE MEDIA TEXT ON A SPORTS THEME
}

The article is devoted to the analysis of media texts expressive means sportswriter at the lexical level (stylistically colored vocabulary, case law, paths, paradigmatic connections, deviations from the norms, etc.). The author shows the quantitative characteristics of the identified means of expression and the dependence of their use on the text.

Keywords: expression, media text, means of imagery, stylistically coloured vocabulary

\section{ВВЕДЕНИЕ}

Газетный стиль занимает особое место среди других стилей благодаря тому, что средства печати отображают современное состояние языка. Газета является средством информации и убеждения. Своеобразие информационно-содержательной функции, выполняемой публицистическим стилем, заключается в том, что, во-первых, информация в этой сфере общественных отношений адресуется не узкому кругу специалистов, как, например, в сфере науки, а широким массам, всем носителям языка; во-вторых, здесь необходима быстрота передачи информации, что не является необходимым, например, в официально-деловом стиле (публицистика, как правило, посвящена «злобе дня»). Функция сообщения лишь передает какую-либо информацию, а воздействия - влияет на ее восприятие. В этом стиле автор не только передает факты, но и выражает свое к ним отношение. 
Поскольку «публицистика берет на себя - в точном смысле этого слова - ответственность за нормальное функционирование общественного мнения ${ }^{1}$, таким образом, она определяет адекватную социальную активность людей. Публицистический стиль характерен не только для печатных изданий, но и для выступлений. Таким образом, круг интересов публицистики неограничен, сюда входят: политика, экономика, наука, спорт и другие сферы современной жизни и сознания.

Экспрессивность в газете может создаваться на разных уровнях: фонетическом, словообразовательном, лексическом, морфологическом и синтаксическом.

Данная статья посвящена анализу экспрессивных средств на лексическом и фразеологическом уровнях, т.к. другие - требуют более широкого описания.

Объектом исследования являются средства выражения экспрессии в публицистических текстах спортивной тематики, предметом - особенности использования указанных средств.

Цель статьи - определить своеобразие использования экспрессивных средств в публицистических текстах на спортивную тему.

Для достижения поставленной цели необходимо решить ряд следующих задач:

1) установить, что понимается под термином «экспрессия»;

2) выявить основные средства экспрессивности, применяемые авторами в медиатексте;

3) дать количественную характеристику выявленным средствам;

4) определить роль (функцию) этих средств в публицистическом тексте;

5) показать зависимость использования средств экспрессии от жанровой принадлежности текста.

Исследование посвящено материалам спортивной тематики, так как анализ экспрессивных средств в публикациях на данную тему позволит более подробно описать проблематику.

В данной работе были использованы методы выборки и количественного подсчета.

Источником извлечения фактического материала служила газета «СБ. Беларусь сегодня: администрация президента РБ»

1 М.В. Луканина, Газетный текст через призму теории коммуникаций, «Вестник Московского университета» 2003, т. 19, № 2, с. 125. 
периода 2011-2012 гг. Общее количество фактического материала составляет 200 случаев употребления.

\section{ОПРЕДЕЛЕНИЕ ПОНЯТИЯ «ЭКСПРЕССИЯ»}

Существует множество определений понятия «экспрессия». Различные авторы дают определения иногда прямо противоположные.

Например, в Большом словаре иностранных слов: «экспрессия [рэ], экспрессии, мн. нет, ж. [латин. expressio - выражение] (книжн.). То, что придает выразительность чему-нибудь, что делает что-нибудь выразительным ${ }^{2}$, т.е. имеется в виду, что экспрессия является «орудием» выразительности, лишь его составной частью. Дмитрий Николаевич Ушаков солидарен с авторами данного словаря 3 .

В Словаре русского языка Анастасии Петровны Евгеньевой под экспрессией понимают «[от лат. expressio - выражение] выразительность, сила и яркость выражения, проявления (какихлибо чувств, переживаний и т.п.)»4.

О разнообразном понимании рассматриваемого термина свидетельствуют и данные словарей синонимов.

Например, в Словаре синонимов Тришина Владимира Никифоровича «экспрессия - сущ., кол-во синонимов (14): выпуклость, выразительность, живописность, живость, картинность, колоритность, красноречивость, красочность, образность, рельефность, сила, сочность, экспрессивность, яркость»5.

Рассмотрев эти синонимы, можно сказать, что чаще употребляемыми синонимами являются выпуклость и выразительность. Также часто используются живописность и живость. Наиболее же редко употребляемыми являются экспрессивность и яркость, т.к. они, видимо, менее соотносимы с понятием «экспрессия».

Научные труды языковедов также свидетельствуют о противоречиях понимания анализируемого термина.

${ }^{2}$ А.Н. Булыко (ред.), Большой словарь иноязычных слов, МАРТИН, Москва 2004, c. 677.

3 Д.Н. Ушаков (ред.), Толковый словарь Ушакова, Государственное издание иностранных и национальных словарей, Москва 1940, с. 1408.

4 А.П. Евгеньева (ред.), Словарь русского языка, Русский язык, Москва 1988, c. 752.

5 В.Н. Тришин (ред.), Словарь синонимов, ASIS, 2010, с. 811. 
Шарль Балли «экспрессивное» приравнивал к «аффективному», как выражение отношения говорящего. Языковед первым доказал, что аффективный фактор является обязательным компонентом любого высказывания и различие в языке интеллектуального и аффективного имеет решающее значение 6 .

Мысль о том, что аффективное является непременным сопроводителем логической стороны сообщения, высказывал и Жан Вандриес. Он считал «экспрессивность» неотъемлемой частью любого высказывания 7 .

В свою очередь Вилем Матезиус, член Пражского лингвистического кружка, утверждал:

высказывание, с одной стороны, охватывает те явления действительности, которые настолько привлекли наше внимание, что мы хотим о них что-то сказать, с другой стороны - выражает наше отношение к этой деятельности $[\ldots]^{8}$,

т.е. наши высказывания содержат как информационную, так и эмоциональную часть.

Роман Осипович Якобсон в объяснении экспрессивного солидарен с Шарлем Балли:

Так называемая эмотивная, или экспрессивная функция имеет своей целью прямое выражение отношения говорящего к тому, о чём он говорит ${ }^{9}$.

Таким образом, при сближении аффективного и эмоционального образуется целый ряд сложно соотнесённых между собой понятий: аффективное, экспрессивное, эмоциональное, оценочное, образное, стилистически окрашенное и т. п. Виктор Кондратьевич Харченко делает вполне обоснованное наблюдение, что внести ясность в этот вопрос чрезвычайно трудно ${ }^{10}$.

В своё время Евдокия Михайловна Галкина-Федорук провела разграничение экспрессивного и эмоционального, доказав,

6 Ш. Балли, Французская стилистика, Либроком, Москва 2009, с. 29.

7 Ж. Вандриес, Язык: лингвистическое введение в историю, пер. Ж. Вандриес, примеч. П.С. Кузнецова, ред. и предисл. Р.О. Шор, Гос. соц.-экон. изд-во, Москва 1937, с. 101.

8 В. Матезиус, Язык и стиль, пер. Г.Я. Романовой, Пражский лингвистический кружок, Прогресс, Москва 1967, с. 447.

9 Р.О. Якобсон, Лингвистика и поэтика, Е.Я. Басина, М.Я. Полякова (ред.), Структурализм: «за» и «против», Прогресс, Москва 1975, с. 198.

${ }^{10}$ В.К. Харченко, Разграничение оценочности, образности, экспрессии и эмоцииональности в семантике слова, «Русский язык в школе» 1976, № 3, с. 70. 
что экспрессия возможна без эмоции. Она утверждала: «Выражение эмоции в языке всегда экспрессивно, но экспрессия в языке не всегда эмоциональна ${ }^{11},-$ и сделала вполне обоснованный вывод, что понятие экспрессивного шире понятия эмоционального.

Таким образом, можно утверждать, что самым главным различием эмоционального и экспрессивного является непроизвольность, непреднамеренность эмоций, так как они связаны с чувствами. А задача экспрессии - преднамеренное использование говорящим (пишущим) определенных языковых средств с целью воздействия на адресата.

Так, изучив мнения различных научных деятелей, можем сделать вывод, что ученые до сих пор не могут прийти к единому мнению в понятии «экспрессия». Наиболее частотным пониманием является: экспрессия - отношение говорящего к тому, о чем он сообщает.

В настоящей работе под «экспрессией» понимается «яркое, глубокое выражение или проявление какого-либо чувства, настроения, переживания» ${ }^{12}$.

\section{ХАРАКТЕРИСТИКА ЯЗЫКОВЫХ СРЕДСТВ, ИСПОЛЬЗУЕМЫХ ДЛЯ СОЗДАНИЯ РЕЧЕВОЙ ЭКСПРЕССИИ}

В современных исследованиях по функциональной стилистике делаются попытки описания средств экспрессивности на всех языковых уровнях.

В литературе представлены следующие уровни:

1) словообразовательный;

2) лексический;

3) синтаксический;

4) сочетание данных уровней в одном слове и др.

Средства лексического уровня являются объектом рассмотрения в работах таких ученых, как Лилии Валентиновны Чернец, Дариуша Фарона, Рустама Раиловича Хабирова, Александры Стефановны Макаровой и др.

${ }^{11}$ Е.М. Галкина-Федорук, Об экспрессивности и эмоциональности, А. И. Ефимова (ред.), Сборник статей по языкознанию, Наука, Москва 1958, с. 121.

${ }^{12}$ Т.Ф. Ефремова, Новый словарь русского языка. Толково-словообразовательный, Русский язык, Москва 2000, с. 698. 
Чернец описывает иронию как стилистический прием. Ирония характерна для публицистического стиля, она состоит в том, когда с видом насмешливым или шуточным говорят противоположное тому, что думают.

Термин «ирония» имеет и другое, более широкое, значение - это эстетическая категория, переходная форма от юмора к сатире, «насмешка, основанная на чувстве превосходства, говорящего над тем, к кому он обращается, в ней в известной мере скрыт обидный оттенок» ${ }^{13}$. Ирония выражает негативное отношение к предмету и является средством выражения экспрессии в публицистике.

Стоит отметить, что в публицистике особое место занимают тексты на спортивную тему, где часто можно встретить экспрессивную лексику.

Фарон писал об использовании просторечной лексики, которая проявляется в свободном диалоге между комментатором и публикой о том, что происходит на стадионе ${ }^{14}$.

Современные языковеды посвятили свои работы также особенностям высказываний самих спортсменов. Стефан Вертлевски, в свою очередь, обратил внимание на синонимический ряд как средство создания экспрессии ${ }^{15}$.

«При помощи фразеологизмов журналисты точно и лаконично характеризуют действия субъектов спортивной деятельности, ситуации и самих спортсменов ${ }^{16}-$ отмечает Хабиров.

Макарова обратила внимание на использование в газетных текстах крылатых выражений-галлицизмов, которые «привлекают внимание читающей аудитории ${ }^{17}$. Автор сравнивает данные выражения в современной российской и французской публицистике.

13 Л.В. Чернец, Ирония как стилистический прием, «Русская словесность» 2001, № 5 , c. 69.

${ }^{14}$ D. Faron, Nowe tendencje $w$ komentarzu sportowym, «Security, Economy and Law» 2015, № 4, c. 86-95.

${ }^{15}$ S. Wiertlewski, Wiele słów, niewiele znaczeń? Synonimia i homonimia/polisemia $w$ socjolekcie rowerowym, «Język, Komunikacja, Informacja» 2016, т. 11, c. 75.

${ }^{16}$ Р.Р. Хабиров, Коммуникативно-прагматический аспект исследования медиатекста (на материале спортивных текстов Республики Башкортостан), Уфа 2016, с. 118.

17 А.С. Макарова, Особенности функционирования крылатых выраженийгаллицизмов в современной французской и российской публицистике, Москва 2016, с. 105. 
Экспрессивная газетная речь активно воздействует на сознание читателя. Она не просто акцентирует его внимание на определенных (нужных журналисту) моментах, но и повышает мыслительную деятельность читателей при восприятии целого текста (или его части), формирует образное представление речемыслительного акта, обеспечивает «накопление смыслов», расширяет содержание, усиливает сказанное.

\section{АНАЛИЗ ФАКТИЧЕСКОГО МАТЕРИАЛА}

\section{ИСПОЛЬЗОВАНИЕ В ПУБЛИЦИСТИЧЕСКОМ ТЕКСТЕ СТИЛИСТИЧЕСКИ ОКРАШЕННОЙ ЛЕКСИКИ}

Стилистически окрашенные единицы (средства, ресурсы) языка - это единицы, обладающие стилистической окраской, выявляемой на фоне нейтральных единиц. Под стилистической окраской языковой единицы понимают дополнительные (коннотативные) к ее основному (номинативному, предметнологическому и грамматическому) значению эмоциональнооценочные, экспрессивные и функциональные свойства. Эти свойства ограничивают употребление единиц языка определенными сферами, стилями, жанрами и условиями общения (ситуацией) и тем самым несут стилистическую информацию ${ }^{18}$.

Выделяется два вида стилистической окраски:

1. Функционально-стилистическая (стилевая) окраска окрашивает само слово как языковую единицу. Она обусловлена частым использованием той или иной единицы языка в определенном его стиле. Как следствие этого процесса, фраза получает окраску, отпечаток данной сферы или стиля, в которой она используется, т.е. слово несет на себе окраску деловой, официальной, научной, публицистической и т. п. речи ${ }^{19}$.

2. Эмоционально-оценочная (стилистическая) - производится «окраска» данных объектов, выражается отношение к ним, даётся им оценка и др. Эта окраска характерна языковой единице, которая не отделена от ее значения. Она может выра-

${ }_{18}$ Т. Г. Винокур, О содержании некоторых стилистических понятий, В. Д. Левин (ред.), Стилистические исследования, Наука, Москва 1972, с. 16.

19 М.Н. Кожина, Л. Р. Дускаева, В.А. Салимовский, Стилистика русского языка, Флинта: Наука, Москва 2008, с. 28. 
жаться в каждой сфере её использования, как в сочетании с другими словами, так и самостоятельно ${ }^{20}$.

В использованном материале для передачи мыслей журналисты прибегают к следующим стилистически окрашенным средствам:

1. Книжным (единицы чаще употребляются в речи автора, их функция - подчеркнуть, придать значение тому или иному явлению):

Жизнь дарит нам прекрасные моменты, награждая встречами с людьми, которые дают уникальную возможность перенять у них прожитый опыт, вкусить и, пережевав, усвоить питательными свойствами мудрость сказанных слов, попытаться понять и нащупать нужную дорогу, стать сильнее ${ }^{21}$.

2. Разговорным. Употребление таких слов характерно как для речи автора, так и для речи персонажа, но чаще - в первом случае. Функция их употребления - передача определённого отношения к:

\section{а) собеседнику:}

Я [Александр Устинов] говорю: «Дружище, не хочу вспоминать»²2.

Характер для борца - самая важная составляющая, и сегодня этот кряжистый коротышка на коне и улыбается счастливой улыбкой призёра мирового первенства во все свои $32^{23}$.

б) объекту описания:

Кличко его [Дэвида Хэя] три года отлавливал... ${ }^{24}$.

Приехал Кинг к Ленноксу и огромный золотой перстень на стол перед ним положил. «Подарок», - говорит, а по ходу дела предложил какой-то сомнительный бой организовать 25.

3. Просторечным (чаще употребляются в основном тексте (речи персонажа). Их функция, как и в случаях с разговорными средствами, связана с отношением говорящего к собеседнику, в данном случае, неодобрительное):

\footnotetext{
${ }^{20}$ Там же, с. 32.

${ }^{21}$ СБ. Беларусь сегодня: администрация президента РБ, Минск, 2011, 19. 10.

22 Там же, 2011, 11. 11.

${ }^{23}$ Там же, 2011, 14. 09.

${ }^{24}$ Там же, 2011, 11. 11.

25 Там же.
} 
А с этим аферюгой Доном Кингом ты знаком?26

А то, что он аферюга, - это сто процентов... ${ }^{27}$.

Когда выходят на ринг два молодца и с хорошей амплитудой друг друга молотят так, что кровью первые ряды забрызгивают... ${ }^{28}$.

В анализируемом материале представлены как слова с положительной, так и отрицательной эмоционально-оценочной окраской. Чаще всего такие единицы встречаются в речи автора, за исключением бранных слов, что связано с резко-негативным отношением персонажа к (кому)чему-либо.

Среди положительных оттенков отмечены:

а) торжественный, возвышенный:

Континентальная хоккейная лига обнародовала новый календарь этого сезона ${ }^{29}$.

Дома Герасименя была принята с почестями ${ }^{30}$.

б) одобрительный:

У нашей национальной сборной период неудач. Белорусские болельщики снова остались без топ-турнира». Много причин. Одна из них - не хватило такого дядьки, как Саша Глеб. Большой мастер. Полезен не только на поле, но и за его пределами. В нужный момент может успокоить, подбодрить. А без этого никуда - сборная у нас сейчас молодая ${ }^{31}$.

\section{в) ласкательный:}

Ну и дома, конечно, когда батя стол накроет, от его «давай, сынок, домашней по три стопочки» никуда не денешься ${ }^{32}$.

\section{г) шутливый:}

Эта медаль стала для него началом большого пути, помимо удовлетворения собственных амбиций и веры в свои силы, она принесла борцу ещё и материальные блага - квартиру в Борисове, где сегодня прописался новоиспечённый серебряный призёр чемпионата мира и наша олимпийская надежда ${ }^{33}$.

\footnotetext{
${ }^{26}$ Там же.

${ }_{27}^{27}$ Там же.

${ }^{28}$ Там же.

${ }^{29}$ Там же, 2011, 14. 09.

зо Там же, 2011, 01. 12.

${ }^{31}$ Там же, 2011, 19. 10.

${ }^{22}$ Там же, 2011, 11. 11.

33 Там же, 2011, 14. 09.
} 
Среди отрицательных оттенков можно выделить:

а) неодобрительный:

Как вы относитесь к тому, что в «Динамо» столь сильная текучка кадров?34 Дебютный сезон «Динамо» в престижной лиге запомнился больше даже не результатами, а поразительной чехардой на тренерском мостике ${ }^{35}$.

Возвращаясь из Афин, я понимал, что вся эта шумиха вокруг ненадолго ${ }^{36}$.

б) иронический:

Тимофей хоть и не сумел долезть до малого финала, однако нужно было видеть, чего это ему стоило ${ }^{37}$.

в) фамильярный, пренебрежительный:

Переезд в Минск стал для него шансом, за который Элбек уцепился зубами $^{38}$.

Над чем работать, он знает, а обидные слова, которые были брошены в лицо. Дейниченко после окончания дня тренерским штабом, настоящего мужика должны лишь подстегнуть ${ }^{39}$.

г) бранный:

Как даст по мордам!40

Я сам его просил: «Бафалиевич, врежьте мне, не могу проснуться» ${ }^{1}$.

Стилистически окрашенная лексика преобладает в речи персонажа.

РЕАЛИЗАЦИЯ В ПУБЛИЦИСТИЧЕСКОМ ТЕКСТЕ

ПАРАДИГМАТИЧЕСКИХ СВЯЗЕЙ

Парадигматические связи - это системные отношения в группах слов, объединяемых общностью признаков ${ }^{42}$ В исследованном

34 Там же.

35 Там же.

${ }^{36}$ Там же, 2011, 16. 12.

37 Там же, 2011, 14. 09.

${ }^{38}$ Там же.

39 Там же.

${ }^{40}$ Там же, 2011, 15. 09.

${ }^{41}$ Там же.

$4^{42}$ С.И. Ожегов, Н.Ю. Шведова (ред.), Словарь русского языка..., с. 623. 
материале они представлены антонимами, которыми являются пары слов, связанные с противоположностью значений, и синонимами, которые имеют сходство значений.

В материалах на спортивную тему авторы используют антонимы для создания более выразительного контраста признаков, которые способствуют раскрытию противоречивой сущности действий и состояний:

Маленький футбол с большими амбициями ${ }^{43}$.

Черно-белый мяч на расовой почве ${ }^{44}$.

Встречаются также и контекстуальные антонимы, например:

В Турции - сухо, в Москве - тревожно ${ }^{45}$.

Синонимы, находящиеся в определенном контексте, выполняют функцию уточнения, они связаны с желанием говорящего или пишущего более чётко передать мысль:

Такое впечатление у всех складывается, - смеется он [Александр Устинов], - что если большой, то неизменно добрый ${ }^{4}$.

Минск и спорт - близнецы-братья ${ }^{47}$.

Антонимы и синонимы преобладают в заголовках.

\section{ОТСТУПЛЕНИЯ ОТ НОРМ КАК СРЕДСТВА СОЗДАНИЯ ЭКСПРЕССИИ}

Не всегда отступление от нормы - ошибка (стилистическая, синтаксическая и т.д.). В ряде случаев именно оно является средством создания выразительности.

В экспрессивной речи к оценке лексической сочетаемости нельзя подходить с обычной меркой, здесь законы «притяжения» слов друг к другу особые. Именно нарушения привычных связей слов, придающие им новые оттенки значения, являются экспрессивными.

\footnotetext{
43 Там же, 2011, 15. 12.

44 Там же, 2011, 22. 12.

45 Там же, 2012, 02. 03.

${ }^{46}$ Там же, 2011, 11. 11.

47 Там же, 2012, 06. 01.
} 
Нарушение лексической сочетаемости может стать действенным средством создания иронического звучания речи: БАТЭ-

«Милан»: разговор без памперсов ${ }^{48}$.

Три снайпера с клюшками ${ }^{49}$.

Подобная несочетаемость делает броскими заголовки. В исследованном материале данный приём используется наиболее часто:

Шайбы для размышления ${ }^{50}$.

«Динамо» проигрывает характеру ${ }^{51}$.

Вратарь у воды ${ }^{52}$.

Публицисты чаще используют данное средство для создания экспрессии в заголовках.

\section{ПРЕЦЕДЕНТНАЯ ЕДИНИЦА КАК СРЕДСТВО СОЗДАНИЯ ЭКСПРЕССИИ}

Прецедентная (от лат. praecedens (praecedentis) - предшествующий) единица - это единица, хорошо известная данной языковой личности и ее «широкому окружению, включая предшественников и современников» 53 .

Употребление этого средства зафиксировано только в заголовках, видимо, для того, чтобы заинтересовать читателя «броскими» и знакомыми для него названиями.

Авторы исследованных публикаций ссылаются на следующие источники:

1. Исторический персонаж:

Тамерлан из Борисова 54 .

Тропой Кутузова ${ }^{55}$.

${ }^{48}$ Там же, 2011, 03. 11.

49 Там же, 2012, 04. 01.

${ }^{\circ 0}$ Там же, 2011, 14. 09.

${ }^{51}$ Там же, 2012, 03. 03.

$5^{2}$ Там же, 2011, 08. 10.

53 Э.Г. Азимов, А.Н. Щукин (ред.), Новый словарь методических терминов и понятий (теория и практика обучения языкам), ИКАР, Москва 2009, c. 86.

54 Там же, 2011, 14. 09.

55 Там же, 2011, 19. 10. 


\section{2. Песня:}

Мирному не хочется покоя ${ }^{6}$.

На лед выходят настоящие мужчины ${ }^{57}$.

За милых дам ${ }^{58}$.

\section{3. Художественные произведения:}

Если мяч приручили, то теперь за него в ответе ${ }^{59}$ (Фраза Антуана де СентЭкзюпери в сказке Маленький принц: «Ты навсегда в ответе за всех, кого приручил»).

Бить или не быть ${ }^{60}$ (Монолог Гамлета из одноименной трагедии: «Быть или не быть?»).

4. Высказывания знаменитых людей:

Надежды «Юность» питают ${ }^{61}$ (Ломоносовское выражение «Надежды юношей питают»).

Прийти, увидеть, победить ${ }^{62}$ (Слова Юлия Цезаря «Пришел. Увидел. Победил»).

\section{5. Фильм:}

Весна на гандбольной улице ${ }^{63}$.

\section{ИСПОЛЬЗОВАНИЕ ФРАЗЕОЛОГИЗМОВ}

В КАЧЕСТВЕ СРЕДСТВА ЭКСПРЕССИИ

Авторы публикаций также обращаются к фразеологическому богатству родного языка как к неисчерпаемому источнику речевой экспрессии.

Присущая фразеологизмам образность оживляет повествование, нередко придает ему шутливую, ироническую окраску:

Как бы к 8 декабря нам не достали кота в мешке ${ }^{64}$.

\footnotetext{
${ }^{56}$ Там же, 2012, 10. 02.

57 Там же, 2012, 04. 01.

${ }^{58}$ Там же, 2012, 01.02.

59 Там же, 2012, 17. 01.

${ }^{60}$ Там же, 2012, 20. 01.

${ }^{61}$ Там же, 2012, 08. 09.

${ }^{62}$ Там же, 2012, 09. 02.

${ }_{63}$ Там же, 2012, 21. 02.

${ }^{64}$ Там же, 2011, 11. 11.
} 
Что ж, будем считать, что это поражение как нельзя кстати ${ }^{65}$.

В исследованном материале встречается:

1) нейтральная фразеология:

Тренер Назаров вышел из себя ${ }^{66}$.

2) стилистически окрашенные устойчивые обороты, что придаёт авторской речи атмосферу непринуждённой беседы условного рассказчика с читателем, воссоздают картину живого общения:

\section{1. Книжные выражения:}

Мне повезло закладывать фундамент будущих побед ${ }^{67}$.

Шайба как оружие массового поражения ${ }^{68}$.

\section{2. Разговорные:}

А совмещать и гнаться сразу за двумя зайцами - это большой риск ${ }^{69}$.

Там все так же уделяют внимание каждой мелочи, с футболистов сдувают пылинки и нет в команде игрока, оклад которого был бы меньше, чем миллион ${ }^{70}$.

\section{3. Просторечные:}

Он за пять минут тебя в такое состояние введёт, так тряхнет, что глаза на лоб вылезают, так заряжаешься!"1.

Возможности применения фразеологизмов значительно шире, чем простое воспроизведение их в речи. Фразеологические богатства языка оживают под пером талантливых писателей, публицистов и становятся источником новых художественных образов, шуток, неожиданных каламбуров. Художники могут обращаться с фразеологизмами как с «сырьем», которое подлежит «творческой обработке» ${ }^{2}$.

${ }_{65}$ Там же, 2011, 14. 09.

${ }^{66}$ Там же, 2011, 09. 11.

67 Там же, 2011, 19. 10.

${ }^{68}$ Там же, 2012, 18. 02.

69 Там же, 2011, 19. 10.

70 Там же.

${ }^{71}$ Там же, 2011, 15. 09.

${ }^{72}$ И. Б. Голуб, Стилистика русского языка, Айрис-Пресс, Москва 2010, с. 26. 
В результате фразеологического новаторства публицистов возникают оригинальные словесные образы, в основе которых «обыгранные» устойчивые выражения. Творческая обработка фразеологизмов придает им новую экспрессивную окраску, усиливая их выразительность. Чаще всего писатели преобразуют фразеологизмы, которые имеют высокую степень устойчивости лексического состава и выполняют в речи экспрессивную функцию. При этом измененные фразеологизмы сохраняют художественные достоинства общенародных - образность, афористичность, ритмико-мелодическую упорядоченность ${ }^{73}$ :

Хотел [Дон Кинг] взять его [Владимира Кличко] под свое крыло74.

В данном случае произошла словообразовательная замена компонента (Брать (взять) под крылышко).

Изменение состава фразеологизма может стать средством усиления экспрессивной окраски речи:

Хватит ходить на цыпочках ${ }^{75}$.

Привычка побеждать стала второй натурой ${ }^{6}$.

Однако в проанализированных публикациях встречаются и фразеологизмы без трансформации:

В конце марта 2008 года руководство КХЛ официально дало «добро» на участие в чемпионате белорусского клуба ${ }^{77}$.

Второй сезон в КХЛ для «Динамо» получился как две капли воды похож на первый ${ }^{7}$.

Использование данного приёма преобладает в жанре интервью, в речи персонажа.

\section{ТРОПЫ КАК СРЕДСТВА СОЗДАНИЯ ЭКСПРЕССИИ}

Особую роль в создании яркой речи играют тропы (гр. tropos поворот, оборот, образ) - слова, употребленные в переносном значении с целью создания образа ${ }^{79}$.

73 Там же, с. 24.

${ }^{74}$ СБ. Беларусь сегодня..., 2011, 11. 11.

75 Там же, 2011, 19. 10.

${ }^{76}$ Там же, 2012, 21. 02.

77 Там же, 2011, 14. 09.

78 Там же.

${ }^{79}$ С.И. Ожегов, Н.Ю. Шведова (ред.), Словарь русского языка..., с. 512. 
Тропы придают наглядность изображению тех или иных предметов, явлений. Например:

Молодая кровь нашего спорта кипит надеждами ${ }^{80}$.

Азаренко блестяще начала теннисный сезон ${ }^{81}$.

Выступая как тропы, обыкновенные слова могут приобрести большую выразительную силу, например:

Жесткий бой с собой ${ }^{82}$.

Теннис в сослагательном наклонении ${ }^{83}$.

В исследованном материале широко представлена метафора. Традиционное определение метафоры связано с этимологическим объяснением самого термина: метафора (гр. metaphora перенос) - это перенос название с одного предмета на другой на основании сходства ${ }^{84}$, например:

Хорошее настроение можно догнать на лыжах ${ }^{85}$.

Чемпионы вырастают из коньков ${ }^{86}$.

Футбол с оттенком грусти ${ }^{87}$.

Среди проанализированных примеров встречается также олицетворение, т.е. наделение неодушевленных предметов признаками и свойствами человека ${ }^{88}$ :

У Гаража с веслом любовь ${ }^{89}$.

Не остаются без внимания авторов и сравнения - сопоставление одного предмета с другим с целью художественного описания первого ${ }^{90}$. Сравнения широко используют публицисты как средство яркой речевой экспрессии:

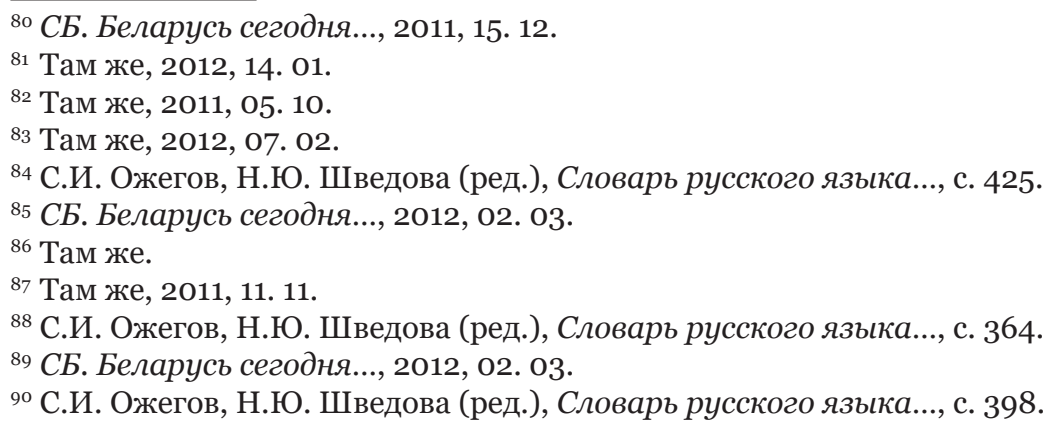


ЛЕКСИКО-ФРАЗЕОЛОГИЧЕСКИЕ СРЕДСТВА...

Год промчался, как миг ${ }^{91}$.

Минск-Арена» стала театром для танцев на льду ${ }^{92}$.

Чаще всего эти средства экспрессии встречаются при создании заголовка.

\section{ЗАКЛЮЧЕНИЕ}

Анализ фактического материала позволяет сделать следующие выводы:

В публицистических текстах на спортивную тему, опубликованных в газете «СБ. Беларусь сегодня», авторы прибегают к разнообразным приёмам создания экспрессии.

1. Из них отдаётся предпочтение образным средствам - тропам. Их количество составляет $22 \%$ от общего числа случаев употребления. При этом названные средства представлены следующим образом: метафора $-47,7 \%$, метонимия $-13,6 \%$; олицетворение - 11, 4\% и сравнение - 27,3\%.

2. Второе место по использованию занимает стилистически окрашенная лексика $(19,5 \%)$, из которой преобладает разговорная лексика, её количество составляет 12,8\%.

3. Авторы прибегают также и к такому приёму, как аллюзия - $17 \%$. Более часто ссылаются на художественные произведения $-31,1 \%$, затем на песню - 19,4\%, реже - на исторический персонаж $-16,5 \%$, фильм $-16,5 \%$, высказывания знаменитых людей $-16,5 \%$.

4. Активны среди средств создания экспрессии и фразеологизмы - 15\%. Преобладает использование нейтральной фразеологии $-36,7 \%$ и трансформированных фразеологизмов с лексической заменой компонента - 20\%, но также встречаются и стилистически окрашенные фразеологизмы - 30\% и обороты без трансформации - 13,3\%.

5. Заметно реже используются отступления от норм $-14,5 \%$.

6. В публицистической речи употребление этих средств связано с созданием выразительности, оценочности и привлечения внимания.

7. Выявленные средства используются как в заголовках, так и в основной части публикации:

${ }^{91}$ СБ. Беларусь сегодня..., 2011, 23. 12.

${ }_{92}$ Там же, 2012, 28. 02. 
1) в заголовках преобладают аллюзия $-38,5 \%$, тропы $-22,1 \%$ и отступления от норм $-19,2 \%$. Их роль заключается в привлечении внимания читателей.

2) в основном тексте отдаётся предпочтение тропам - 22,5 \% и стилистически окрашенной лексике - 19,5\%, менее употребительны фразеологизмам - 15\%, отступления от норм $-14,5 \%$ и антонимы, синонимы - $12 \%$ :

a) в жанре статьи на первый план выходят стилистически окрашенная лексика - 50\%, затем - использование фразеологизмов $-20 \%$ и целенаправленное нарушение норм $-13 \%$;

б) в жанре интервью также преобладает стилистически окрашенная лексика $-50 \%$, реже используются фразеологизмы $-35 \%$.

\section{REFERENCES}

Azimov, El'khan, Shchukin, Anatoliy (Ed.), Novyy slovar' metodicheskikh terminov i ponyatiy (teoriya i praktika obucheniya yazykam). Moskva: IKAR, 2009 [Азимов, Эльхан, Щукин, Анатолий (ред.), Новый словарь методических терминов и понятий (теория и практика обучения языкам). Москва: ИКАР, 2009].

Balli, Sharl'. Frantsuzskaya stilistika. Moskva: Librokom, 2009 [Балли, Шарль. Французская стилистика. Москва: Либроком, 2009].

Bulyko, Aleksandr (Ed.). Bol'shoy slovar' inoyazychnykh slov. Moskva: MARTIN, 2004 [Булыко, Александр (Ред.). Большой словарь иноязычных слов. Москва: МАРТИН, 2004].

Chernets, Liliya. "Ironiya kak stilisticheskiy priyem.” Russkayaslovesnost' 2001, no. 5: 69 [Чернец, Лилия. "Ирония как стилистический прием.» Русская словесность 2001, по. 5: 69-72].

Faron, Dariusz. "Nowe tendencje w komentarzu sportowym.» Security, Economy and Law 2015, no. 4: 86-95.

Galkina-Fedoruk, Yevdokiya. "Ob ekspressivnosti i emotsional'nosti.» A. I. Yefimova (Ed.), Sbornik statey po yazykoznaniyu. Moskva: Nauka, 1958: 103-124 [Галкина-Федорук, Евдокия. "Об экспрессивности и эмоциональности." А. И. Ефимова (Ред.). Сборник статей по языкознанию. Москва: Наука, 1958: 103-124].

Golub, Irina. Stilistika russkogo yazyka. Moskva: Ayris-Press, 2010 [Голуб, Ирина. Стилистика русского языка. Москва: Айрис-Пресс, 2010].

Khabirov, Rustam. Kommunikativno-pragmaticheskiy aspekt issledovaniya mediateksta (na materiale sportivnykh tekstov Respubliki Bashkortostan). Ufa, 2016 [Хабиров, Рустам. Коммуникативно-прагматический аспект исследования медиатекста (на материале спортивных текстов Республики Башкортостан). Уфа ,2016].

Kharchenko, Vera. "Razgranicheniye otsenochnosti, obraznosti,ekspressii i emotsional'nosti v semantike slova." Russkiy yazykv shkole 1976, no. 3: 66-71. [Xap- 
ченко, Вера. Разграничение оценочности, образности, экспрессии и эмоциональности в семантике слова.” Русский язык в школе 1976, no. 3: 66-71].

Kozhina, Margarita, Duskayeva, Liliya, Salimovskiy, Vladimir. Stilistika russkogo yazyka. Moskva: Nauka, 2008 [Кожина, Маргарита, Дускаева, Лилия, Салимовский, Владимир. Стилистика русского языка. Москва: Наука, 2008].

Lukanina, Mariya. "Gazetnyy tekst cherez prizmu teorii kommunikatsiy." Vestnik Moskovskogo universiteta 2003, t. 19, no. 2: 123-133 [Луканина, Мария. "Газетный текст через призму теории коммуникаций." Вестник Московского университета 2003, т. 19, no. 2: 123-133].

Makarova, Aleksandra. Osobennosti funktsionirovaniya krylatykh vyrazheniygallitsizmov $v$ sovremennoy frantsuzskoy i rossiyskoy publitsistike. Moskva 2016 [Макарова, Александра. Особенности функционирования крылатых выражений-галлицизмов в современной французской и российской публицистике. Москва 2016].

Matezius, Vilem. "Yazyk i stil'." G.Ya. Romanova. Transl., N.A. Kondrashov. Ed. Prazhskiy lingvisticheskiy kruzhok. Moskva:Progress, 1967:444-524[Матезиус, Вилем. “Язык и стиль.” Г.Я. Романова (пер.), Н.А. Кондрашов (сост.-ред.), Пражский лингвистический кружок. Москва: Прогресс, 1967: 444-524].

SB. Belarus' segodnya: administratsiya prezidenta RB. Minsk, 2011 [СБ. Беларусь сегодня: администрация президента РБ. Минск 2011].

SB. Belarus' segodnya: administratsiya prezidenta RB. Minsk, 2012 [СБ. Беларусь сегодня: администрация президента РБ. Минск, 2012].

Trishin, Vitaliy. Ed. Slovar' sinonimov. ASIS, 2010 [Тришин, Виталий. Ред. Словарь синонимов. ASIS, 2010].

Ushakov, Dmitriy. Ed. Tolkovyy slovar' russkogo yazyka. Moskva: Gosudarstvennoye izdatel'stvo inostrannykh i natsional'nykh slovarey, 1940 [Ушаков, Дмитрий. Ред. Толковый словарь русского языка. Москва: Государственное издательство иностранных и национальных словарей, 1940].

Vandriyes, Zhozef. Yazyk: lingvisticheskoye vvedeniye $v$ istoriyu. Transl. Zh. Vandriyes, primech. P.S. Kuznetsova, R. O. Shor. Ed. i pref. Moskva: Gos. sots.-ekon. izd-vo, 1937 [Вандриес, Жозеф. Язык: лингвистическое введение в историю. Пер. Ж. Вандриес, примеч. П.С. Кузнецова; Р.О. Шор. Ред. и предисл. Москва: Гос. соц.-экон. изд-во, 1937].

Vinokur, Tat'yana. O soderzhanii nekotorykh stilisticheskikh ponyatiy. V. D. Levin. Ed. Stilisticheskiye issledovaniya. Moskva: Nauka, 1972 [Винокур, Татьяна. О содержании некоторых стилистических понятий. В.Д. Левин. Ред. Стилистические исследования. Москва: Наука, 1972].

Wiertlewski, Stefan. "Wiele słów, niewiele znaczeń? Synonimia i homonimia/polisemia w socjolekcie rowerowym.” Język, Komunikacja, Informacja 2016, t. 11: 73-85.

Yakobson, Roman. Lingvistika i poetika. Ye.Ya. Basina, M.Ya.Polyakova. Eds. Strukturalizm: "za" $i$ "protiv". Moskva: Progress, 1975: 193-230 [Якобсон, Роман. Лингвистика и поэтика. Е.Я. Басина, М.Я. Полякова. Ред. Структурализм: “за” и “против.” Москва: Прогресс, 1975: 193-230].

Yefremova, Tat'yana. Novyy slovar' russkogo yazyka. Tolkovo-slovoobrazovatel'nyy. Moskva: Russkiy yazyk, 2000 [Ефремова, Татьяна. Новый словарь русского языка. Толково-словообразовательный. Москва: Русский язык, 2000].

Yevgen'yeva, Anastasiya. Ed. Slovar' russkogo yazyka. Moskva: Russkiy yazyk, 1988 [Евгеньева, Анастасия. Ред. Словарь русского языка. Москва: Русский язык, 1988]. 